\title{
Characterization of Calotropis procera root peroxidase and its potential to mediate remediation of phenolic pollutant from petroleum refinery effluent
}

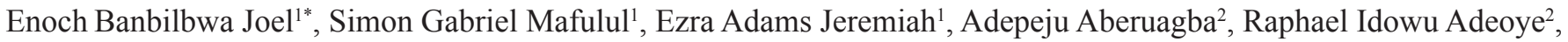 \\ Lazarus Joseph Goje ${ }^{3}$, Adedoyin Igunnu², Sylvia Omonirume Malomo² \\ ${ }^{1}$ Department of Biochemistry, Faculty of Basic Medical Sciences, College of Health Sciences, University of Jos, Jos, Nigeria. \\ ${ }^{2}$ Department of Biochemistry, Faculty of Life Sciences, University of Ilorin, Ilorin, Nigeria. \\ ${ }^{3}$ Department of Biochemistry, Faculty Science, Gombe State University, Gombe, Nigeria.
}

\section{ARTICLE INFO \\ Article history: \\ Received on: January 22, 2021 \\ Accepted on: April 28, 2021 \\ Available online: September 01, 2021}

\section{Key words:}

Calotropis procera, peroxidase, phenol, pollutant, bioremediation, biocatalyst, petroleum effluent

\begin{abstract}
Peroxidases are oxidoreductive enzymes that have the potential to oxidize recalcitrant organic compounds like phenol, reducing their toxicity. Calotropis procera root peroxidase (CPrP) was isolated, characterized, and evaluated at the laboratory scale for its ability to oxidatively degrade phenol in petroleum refinery effluent. Ammonium sulfate precipitation, ion exchange, and gel filtration chromatography were used to purify CPrP 79-fold. Purified CPrP revealed a single polypeptide band with a molecular weight of $46.5 \mathrm{kDa}$ in a single peak. The biochemical characterization revealed that the CPrP is a thermostable enzyme, active on both tested substrates (o-dianisidine and guaiacol) with optimum activity at $50^{\circ} \mathrm{C}$ and $\mathrm{pH} 6.0$. The kinetic data show that $o$-dianisidine is the most preferred substrate. Apart from acetone, ethylenediaminetetraacetic acid, and $\mathrm{Hg}^{2+}$ which act as inhibitors of $\mathrm{CPrP}$, all other tested metal ions $(\mathrm{Mg} 2+, \mathrm{Zn} 2+, \mathrm{Cu} 2+$, and $\mathrm{Mn} 2+)$ exhibited slight activation. The CPrP exhibits high efficiency to bioremediate phenol from petroleum effluent. In conclusion, this study revealed the possibility of obtaining peroxidase from locally available bioresources with the ability to bioremediate phenolic contaminants from petrochemical industry effluents.
\end{abstract}

\section{INTRODUCTION}

One of the most pressing global issues today is toxic chemical contamination of soil, water, and air [1]. The petroleum exploration, refining, and pipeline leakages in the Niger Delta region of Nigeria have resulted in environmental pollution concern over the years [2]. Apart from oil spillage, the discharge of effluents from untreated and insufficiently treated wastewater of oil refineries constitutes another potential source of environmental (water and soil) pollution of public health concern $[2,3]$. Phenol and its derivatives are widely distributed in nature as hazardous pollutants in various industrial effluents like petroleum/petrochemical, coal

\section{*Corresponding Author}

Enoch Banbilbwa Joel, Department of Biochemistry, Faculty of Basic Medical Sciences, College of Health Sciences, University of Jos, Jos, Nigeria.E-mail: enjoebest@yahoo.com conversion, herbicide/pesticide, synthetic rubber, paper, plastics, and textile $[4,5]$.

The US Environmental Protection Agency has designated phenol as a priority pollutant with a permissible limit in wastewater of $0.1 \mathrm{mg} / 1[6,7]$. Phenol and its derivatives are among the most dangerous and carcinogenic organic pollutants found in refinery wastewater, and they are considered to be extremely toxic even at low levels $[6,8]$. Hence, they constitute a serious environmental challenge if discharged untreated or partially treated from industrial effluents into water bodies or land sites [4]. Conventional methods like adsorption on activated carbon, microbial degradation, incineration, chemical oxidation, and use of oxidizing agents such as UV and ozone, and solvent extraction are usually applied to remove phenolic pollutants from wastewater [9]. Conventional methods of phenol removal methods, on the other hand, face major challenges such as lengthy procedures, low performance, and the generation of certain products that are more 
toxic than the original phenolic compounds. As a result, a more flexible alternative approach for treating a wide range of reaction conditions with minimal to no posttreatment environmental effects is needed [10]. Enzyme-mediated bioremediation of effluents containing poisonous organic pollutants appears to be more effective because enzymes have a unique ability to degrade a wide range of pollutants to form nontoxic end products [5]. Enzymes can also transform and render a given pollutant more amenable to treatment or even aid the transformation of waste to value-added products [10]. The enzymatic method is simple and easy to control; more so, it is highly efficient in the degradation of high and low concentrations of targeted pollutants [10].

Peroxidases (EC 1.11.1.7) are heme-containing oxidoreductases that use hydrogen peroxide as an oxidant to catalyze the oxidation of a wide range of substrates like phenols, aromatic amines, sulfonates, and indoles $[11,12]$. They have a wide variety of industrial and biotechnological applications, one of which includes biodegradation of toxic and carcinogenic phenolic contaminants and related compounds in industrial effluents [13]. The horseradish peroxidase (HRP) and other plant peroxidases have been extensively used to bioremediate phenolic compounds from industrial wastewater $[10,14]$. However, the high cost of purified HRP and other commercially available peroxidases has made it necessary to search for other cheap and local sources of peroxidases with comparable or better stability that can be explored for efficient biodegradation of phenolic pollutants from industrial effluents [13]. This approach for searching peroxidase and other useful products from local bioresource with the potential to remediate organic pollutants arising from petroleum effluent would particularly be important to oil-producing countries.

Plants are a well-known source of some biotechnologically important enzymes.

Horseradish roots, soybean seed hulls, and turnip roots, for example, are high in enzymes like catalase, laccase, and peroxidases [5]. Plants, such as horseradish roots, soybean seed hulls, and turnip roots, are a significant source of commercial peroxidases. Plants represent a major source of commercial peroxidases, such as horseradish roots, soybean seed hulls, and turnip root [15]. However, the major limitation for the widespread application of commercial enzymes including peroxidases especially in developing countries is the significant cost of and instability. This challenge can be partly surmounted by searching for an active and stable alternative enzyme from readily abundant local bioresource sources. This is why peroxidases have been characterized from various plant sources such as water broccoli [16], spinach [17], cabbage [18], and waste cabbage [14] in an attempt to search for other alternatives to commercially available peroxidase. Due to food insecurity, the new global system aims to reduce competition with consumable plant foodstuffs for extraction of enzymes and other useful products. Hence, exploring nonconsumable and readily abundant local plants like Calotropis procera as a source of peroxidase would be a better option. We earlier reported the presence of peroxidase from C. procera leaf [19]. However, it has been reported that peroxidases are more abundant primarily in roots and sprouts of higher plants [15]. This study therefore isolated, purified, and characterized peroxidase from C. procera root and evaluated its potential to bioremediate phenol pollutant from petroleum refinery effluent.

\section{MATERIALS AND METHODS}

\subsection{Materials/Reagents}

The effluent samples were taken from the Warri Refinery and Petrochemical Company, a subsidiary of the Nigerian National Petroleum Corporation, in Warri, Delta State, and placed in a clean plastic jar. C. procera root was collected in Bauchi Local Government Area, Bauchi State, Nigeria. Folin Ciocalteu's reagent, bovine serum albumin (BSA), phenol, substrates (o-dianisidine and guaiacol), ethylenediaminetetraacetic acid (EDTA) Sephadex-G-75, diethylaminoethyl sepharose (DEAE)-Sepharose, and acetone were obtained from Sigma Aldrich. All other chemicals were of researchgrade and were procured from commercial sources.

\subsection{Isolation of Crude Peroxidase from $C$. procera Root}

Crude peroxidase was isolated from $C$. procera root according to the method of [20] with slight modification. The fresh root of $C$. procera weighing $50 \mathrm{~g}$ was washed under running tap water and soaked in $100 \mathrm{mM}$ Tris- $\mathrm{HCl}$ buffer, $\mathrm{pH} 7.5$ overnight. Thereafter, the soaked sample was homogenized with $200 \mathrm{ml}$ of $100 \mathrm{mM}$ Tris$\mathrm{HCl}$ buffer, $\mathrm{pH} 7.5$ using Akia homogenizer. To remove suspended particles, cheesecloth was used to filter the homogenized sample and the filtrate was centrifuged at $10,000 \mathrm{~g}$ for 15 minutes at $4^{\circ} \mathrm{C}$. To obtain a clearer filtrate as crude $C$. procera root, the supernatant was carefully filtered through Whatman No. 1 filter paper $C$. procera root peroxidase (CPrP).

\subsection{Determination of Peroxidase Activity and Protein Concentration}

Lowry method was adopted for the determination of protein concentration [21]. The standard protein, BSA was used for the calibration curve. The protein concentration of the unknown sample was then extrapolated from the straight-line equation of the plot of absorbance against the BSA concentration.

Peroxidase activity was estimated spectrophotometrically using a time-course rate of oxidation of o-dianisidine as substrate [22]. Briefly, $2.7 \mathrm{ml}$ of $100 \mathrm{mM}$ phosphate buffer, $\mathrm{pH} 6.0,0.1 \mathrm{ml}$ of the crude enzyme, and $0.1 \mathrm{ml}$ of $5 \mathrm{mM}$-dianisidine were mixed in a test tube. Thereafter, $0.1 \mathrm{ml}$ of $3 \%$ hydrogen peroxide was added to initiate the reaction, and then the change in the absorbance was measured every 20 seconds for 3 minutes at $460 \mathrm{~nm}\left({ }_{\varepsilon} 460\right.$ $\mathrm{nm}=11.3 \mathrm{mM}^{-1} . \mathrm{cm}^{-1}$ ) using UV-Vis spectrophotometer (modelCHEBIOS s.r.l., Rome, Italy).

\subsection{Purification of CPrP}

\subsubsection{Ammonium sulfate precipitation/dialysis of C. procera peroxidase}

Varying concentrations of ammonium sulfate salt were added to the crude enzyme extract to achieve $60 \%$ to $90 \%$ saturation and subjected to stirring for about 4 hours for complete precipitation. The resulting mixture was centrifuged at $10,000 \mathrm{~g}$ for 15 minutes and the pellets of precipitated protein were collected and 
resuspended in a $100 \mathrm{mM}$ Tris- $\mathrm{HCl}$ buffer, $\mathrm{pH}$ 7.5. Each precipitate was then analyzed for peroxidase activity. The peroxidase activity of each precipitate was then determined.

After salting out the protein to eliminate excess salt and other small molecules, dialysis via a semipermeable membrane dialysis tubule is normally performed. The peroxidase activity of the resuspended pellets obtained from $85 \%$ saturation was dialyzed against $0.1 \mathrm{M}$ Tris- $\mathrm{HCl}$ buffer solution, $\mathrm{pH}$ 7.5) by continuous magnetic stirring for 12 hours with six daily buffer changes every 2 hours.

\subsubsection{Ion-exchange chromatography of CPrP on DEAE- Sepharose}

An anion exchange chromatography was performed by loading the dialyzed sample on a DEAE-Sepharose fast-flowing column $(5.0 \times 5.0 \mathrm{~cm})$ preequilibrated with $100 \mathrm{mM}$ Tris $\mathrm{pH}$ 7.5. A linear gradient of $\mathrm{NaCl}(25-100 \mathrm{mM})$ was used to elute the bound proteins, and the fractions were eluted and collected in $2 \mathrm{ml}$ per fraction. The protein content, homogeneity, and peroxidase activity were all measured in the fractions. The active fractions were combined, dialyzed, and then used in the next step.

\subsubsection{Gel filtration chromatography of CPrP on Sephadex-G-75}

The peroxidase-active fractions from "Ammonium sulfate precipitation/dialysis of $C$. procera peroxidase" were pooled and purified further by gel filtration chromatography on a Sephadex-G-75 column $(2.5 \times 20 \mathrm{~cm})$ preequilibrated with 100 $\mathrm{mM}$ Tris $\mathrm{pH}$ 7.5. The peroxidase activity and protein concentration were calculated after fractions of purified enzyme were eluted at a rate of $2 \mathrm{ml}$ per fraction. A single fraction with the highest activity was used as purified peroxidase for the characterization of biochemical properties.

\subsection{Characterization of Biochemical Properties of Purified CPrP}

\subsubsection{Electrophoresis}

Sodium dodecyl sulfate-polyacrylamide gel electrophoresis (SDSPAGE) was used to determine the purity and molecular weight of the purified peroxidase, as described by Laemmli [23]. SDSPAGE was used to verify the purity of the fractions obtained after various purification steps.

The samples and standard protein markers were loaded onto the wells of $4 \%$ stacking gel and were resolved in $12.5 \%$ separating gel. Dye, $0.2 \%$ Coomassie brilliant blue R-250 was used to stain gels. Lysozyme (14 kDa), trypsin inhibitor $(20 \mathrm{kDa})$, pepsin $(36 \mathrm{kDa})$, egg albumin (45 kDa), BSA (68 kD), phosphorylase b (97 kDa), and e-galactosidase $(116 \mathrm{kDa})$ were used as standard protein markers.

The samples and standard protein markers were placed into 4\% stacking gel wells and resolved in a $12.5 \%$ separating gel. $0.2 \%$ of Coomassie brilliant blue R-250 dye was used to stain the gels. Standard protein markers of known molecular weights included lysozyme $(14 \mathrm{kDa})$, trypsin inhibitor $(20 \mathrm{kDa})$, pepsin $(36 \mathrm{kDa})$, egg albumin (45 kDa), BSA (68 kDa), phosphorylase b (97 kDa), and e-galactosidase $(116 \mathrm{kDa})$.

\subsubsection{The effects of $\mathrm{pH}$ on activity of $\mathrm{CPrP}$}

Peroxidase activity was measured in $100 \mathrm{mM}$ phosphate buffer at varying $\mathrm{pH}(4-9)$ to determine the optimum $\mathrm{pH}$ of CPrP.

\subsubsection{Effects of temperature on CPrP activity and stability}

Peroxidase activity was measured at varying temperatures $\left(30^{\circ} \mathrm{C}-80^{\circ} \mathrm{C}\right)$ at 10 -degree intervals to determine the optimum temperature of CPrP.

For thermal stability, the purified $\mathrm{CPrP}$ was preincubated without the substrate for 1 hour at $50^{\circ} \mathrm{C}, 60^{\circ} \mathrm{C}, 70^{\circ} \mathrm{C}$, and $80^{\circ} \mathrm{C}$ and then cooled on ice for 5 minutes prior to assaying for peroxidase activity.

\subsubsection{Determination of kinetic and substrate specificity of $\mathrm{CPrP}$}

To assess the kinetic parameters $\left(K_{\mathrm{m}}\right.$ and $\left.V_{\max }\right)$ of the CPrP, peroxidase activity was assayed at varying concentrations $(0.1-1.0$ $\mathrm{mM}$ ) of the two different substrates (o-dianisidine and guaiacol) with $0.1 \mathrm{ml}$ of purified enzyme. Reactions were initiated by the addition of $3 \%$ of an oxidant; $\mathrm{H}_{2} \mathrm{O}_{2}$ and absorbance measures were converted to peroxidase activities "Determination of peroxidase activity and protein concentration". The plot of double reciprocal of Michaelis-Menten equation was used to determine the kinetic parameters.

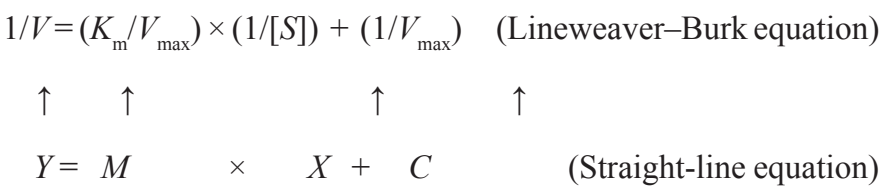

$K_{\mathrm{m}}=$ Michaelis-Menten constant, $V=$ enzyme activity (also known as initial velocity), $V_{\max }=$ maximum velocity (or reaction rate), and $[S]=$ substrate concentration $(\mathrm{mM})$.

\subsubsection{The effects of EDTA, acetone, and metal ions on the activity of $\mathrm{CPrP}$}

The purified CPrP was preincubated with $5 \mathrm{mM}$ concentrations of each metal ion $\left(\mathrm{Mg}^{2+}, \mathrm{Hg}^{2+}, \mathrm{Zn}^{2+}, \mathrm{Cu}^{2+}\right.$, and $\left.\mathrm{Mn}^{2+}\right)$, EDTA, and acetone for 30 minutes at $60^{\circ} \mathrm{C}$ to determined their effects on the activity of CPrP. The activity of peroxidase was then measured as in "Determination of peroxidase activity and protein concentration". The control experiment was done by assaying for peroxidase activity in the absence of metal ions, EDTA, and acetone.

\subsection{Potential Application of CPrP in Oxidative Degradation of Phenol from Petroleum Refinery Effluent}

The 4-aminoantipyrene (4-AAP) method was adopted for quantification of phenol in petroleum effluent before and after CPrP-mediated biodegradation [24]. A phenol standard curve was made using graded concentration (3-12 $\mathrm{mg} / \mathrm{l})$ of pure phenol. It was anticipated that 60 minutes of incubation of effluent with $\mathrm{CPrP}$ is sufficient to demonstrate significant biodegradation of phenol. $10 \mathrm{ml}$ petroleum effluent was aliquoted into a clean flask, followed by the addition of $2 \mathrm{ml}$ of $100 \mathrm{mM}$ phosphate buffer $(\mathrm{pH}$ $6.0), 0.2 \mathrm{ml}$ of $3 \% \mathrm{H}_{2} \mathrm{O}_{2}$, and varying concentrations of partially purified $\operatorname{CPrP}(1,2$, and $4 \mathrm{ml})$. After incubation for 60 minutes at 
$60^{\circ} \mathrm{C}$, the mixture was centrifuged and the residual concentration of phenol was assessed in the supernatant.

To determine the residual phenol concentration, $4 \mathrm{ml}$ of $250 \mathrm{mM}$ sodium bicarbonate and $0.9 \mathrm{ml}$ of $20.8 \mathrm{mM}$ 4-AAP were added to the supernatant and mixed vigorously. Thereafter, $0.9 \mathrm{ml}$ of $83.4 \mathrm{mM}$ potassium ferricyanide was added and allowed to stand for 9 minutes after intensive mixing. Absorbance was read at $\kappa$ $=510 \mathrm{~nm}$ and converted to concentration using the calibration curve of phenol standard. Thereafter, the efficiency of oxidative biodegradation of phenol from the effluent was calculated.

Percentage phenol biodegradation $=\left(C_{\mathrm{I}}-C_{\mathrm{F}}\right) / C_{\mathrm{I}} * 100$

where $C_{\mathrm{I}}=$ initial concentration and $C_{\mathrm{F}}=$ final phenol concentration.

\section{RESULTS}

\subsection{Purification of CPrP}

Peroxidase was successfully isolated from $C$. procera root and purified to a single band by ammonium sulfate precipitation, dialysis, and chromatography (gel filtration and ion exchange). The purity of the CPrP following ammonium sulfate and dialysis checked by slab gel electrophoresis showed multiple bands, which indicates the presence of multiple proteins. The sample was subjected to further purification by DEAE-Sepharose ionexchange chromatography (Fig. 1) and Sephadex-G75 gel filtration chromatography (Fig. 2). After ion-exchange chromatography, two

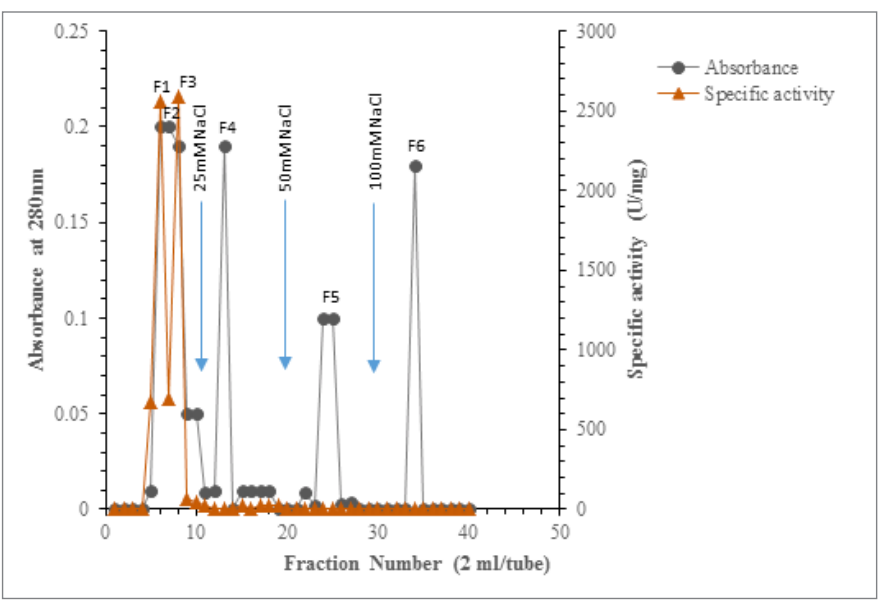

Figure 1: Ion exchange chromatographic elution profile of CPrP purification on DEAE-Sepharose column. The dialyzed fraction was loaded on DEAESepharose column preequilibrated with $0.1 \mathrm{M}$ Tris $\mathrm{pH}$ 7.5. The bound proteins were eluted with a linear gradient of $\mathrm{NaCl}(25-100 \mathrm{mM})$ and the fractions were collected at a flow rate of $2 \mathrm{ml} /$ tube. Protein elution profile was monitored by peroxidase activity and protein concentration. major fractions (F1 and F2) that exhibited peroxidase activity were pooled, combined, and subjected to gel filtration chromatography that resulted in a single peak $(\mathrm{Fa})$ with peroxidase activity. The Fa fraction was pooled and used as purified CPrP for subsequent studies. The summary of the purification steps and the degree of purification obtained at each purification step is presented in Table 1. Peroxidase from CPrP has been purified to homogeneity and the final purification step resulted in 79-fold purification with a recovery of $37.56 \%$.

\subsection{Characterization of Biochemical Properties of Purified CPrP}

\subsubsection{Electrophoresis}

The SDS-PAGE was used to verify the purity of the enzyme and to determine its molecular weight via a slab gel electrophoresis (Fig. 3). After two steps of chromatography, SDS-PAGE analysis of the purified peroxidase showed the existence of a single protein band. With a molecular weight of 46.5 , the single protein band indicates that the purified peroxidase was a single band homogeneous protein (Fig. 3).

\subsubsection{Effect of pH on the CPrP activity}

Figure 4 shows the effect of varying $\mathrm{pH}$ on the activity of $\mathrm{CPrP}$. The purified CPrP exhibited high activity within a broad range of reaching optimal at $\mathrm{pH} 6.0$ (Fig. 4).

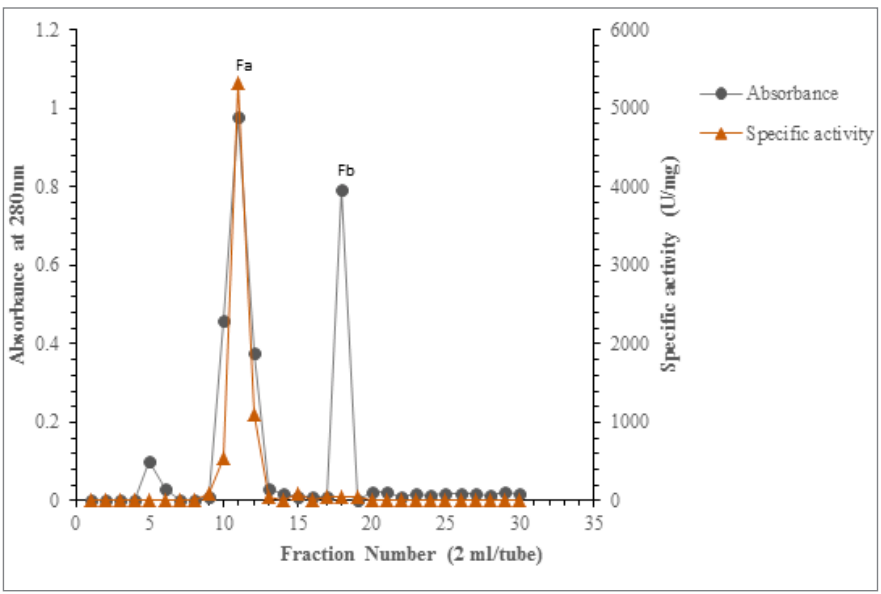

Figure 2: Gel filtration chromatographic elution profile of CPrP purification on Sephadex G-75 column. The active fractions (F1 and F3) from ion exchange chromatography were pooled, combined, dialyzed, and loaded on Sephadex G-75 column pre-equilibrated with elution buffer $100 \mathrm{mM}$ Tris-HCl buffer, $\mathrm{pH}$

7.0. Protein elution profile was monitored by peroxidase activity and protein concentration.

Table 1: Summary of purification of CPrP.

\begin{tabular}{lcccc} 
Purification step & $\begin{array}{c}\text { Total enzyme } \\
\text { activity (U) }\end{array}$ & $\begin{array}{c}\text { Total protein } \\
(\mathbf{m g})\end{array}$ & $\begin{array}{c}\text { Specific activity } \\
\text { (Umg }\end{array}$ & $\begin{array}{c}\text { Recovery (\%) } \\
\text { Purification fold }\end{array}$ \\
Crude extract & 764.66 & 216.33 & 3.53 & 100.00 \\
$\left(\mathrm{NH}_{4}\right)_{2} \mathrm{SO}_{4}$ Precipitation & 653.10 & 66.69 & 9.79 & 85.41 \\
DEAE-Sepharose chromatography & 343.20 & 13.02 & 26.36 & 44.90 \\
Gel filtration (Sephadex G-75) chromatography & 287.25 & 1.03 & 287.88 & 37.56 \\
\hline
\end{tabular}



petroleum refinery effluent 2021;9(05):101-109

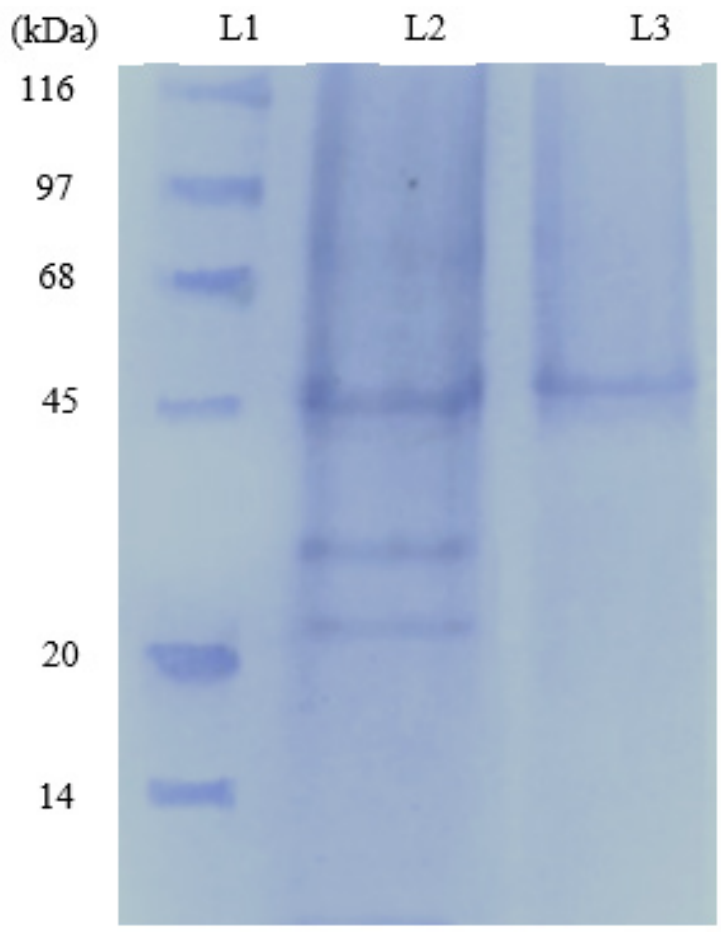

Figure 3: Photographic representation of SDS-PAGE analysis of CPrP. Coomassie brilliant blue R-250 was used for staining. L1: molecular weight markers, L2: extract after $\left(\mathrm{NH}_{4}\right)_{2} \mathrm{SO}_{4}$ and dialysis, L3: purified Colotropis procera root peroxidase after ion exchange and gel filtration chromatography.

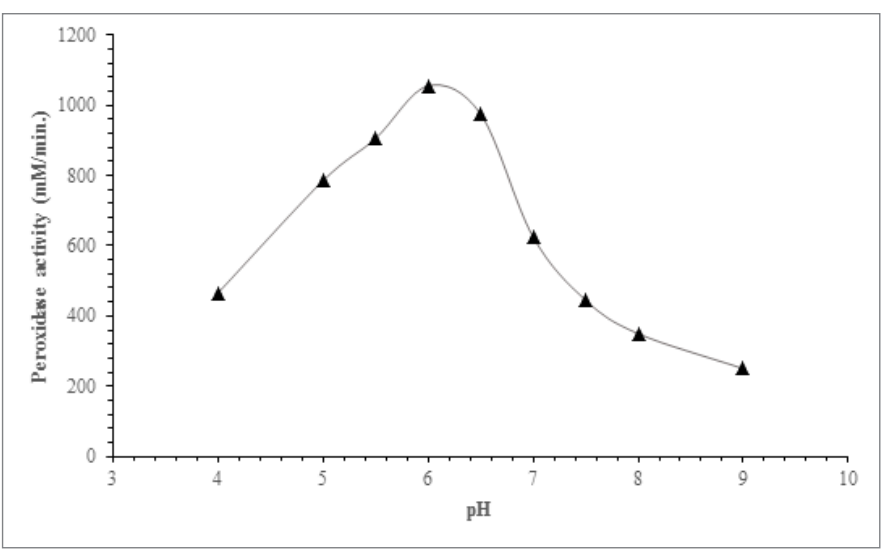

Figure 4: Effect of $\mathrm{pH}$ on the $\mathrm{CPrP}$. In order to determine the optimum $\mathrm{pH}$, peroxidase activity was assayed at varying $\mathrm{pH}(4-9)$. Peroxidase activity was assayed using o-dianinsidine $(5 \mathrm{mM})$ as substrate. Each reaction was initiated by the addition of $3 \%$ of $\mathrm{H}_{2} \mathrm{O}_{2}$ to the reaction mixture containing $2.7 \mathrm{ml}$ of 0.1 M phosphate buffer solution ( $\mathrm{pH}$ 6.0), plus $100 \mu 1$ of crude enzyme and $100 \mu 1$ of substrate and change in A460 was monitored immediately after starting the reaction at 20 -second interval for 3 minutes.

\subsubsection{Effect of temperature on the CPrP activity and stability}

The peroxidase activity of the purified CPrP increased progressively with an increase in temperature, reaching optimum at $60^{\circ} \mathrm{C}$ and then declined gradually (Fig. 5).

The result of thermostability studies showed that CPrP is a relatively thermostable peroxidase at the tested temperatures with over $80 \%$ activity retained at 50 and $60^{\circ} \mathrm{C}$ (Fig. 6). However, only

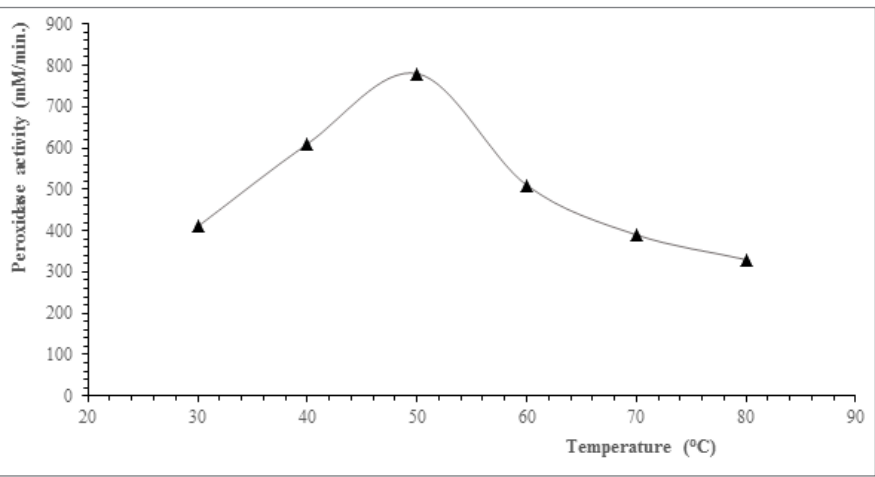

Figure 5: Effect of varying temperature on the CPrP activity. In order to determine the optimum temperature, peroxidase activity was assayed at varying temperatures $\left(30^{\circ} \mathrm{C}, 40^{\circ} \mathrm{C}, 50^{\circ} \mathrm{C}, 60^{\circ} \mathrm{C}, 70^{\circ} \mathrm{C}\right.$, and $\left.80^{\circ} \mathrm{C}\right)$. Peroxidase activity was assayed using o-dianinsidine $(5 \mathrm{mM})$ as substrate. Each reaction was initiated by the addition of $3 \%$ of $\mathrm{H}_{2} \mathrm{O}_{2}$ to the reaction mixture containing $2.7 \mathrm{ml}$ of $0.1 \mathrm{M}$ Phosphate buffer solution (pH 6.0), plus $100 \mu \mathrm{l}$ of crude enzyme, and $100 \mu \mathrm{l}$ of substrate and change in A460 was monitored immediately after starting the reaction at 20 -second intervals for 3 minutes.

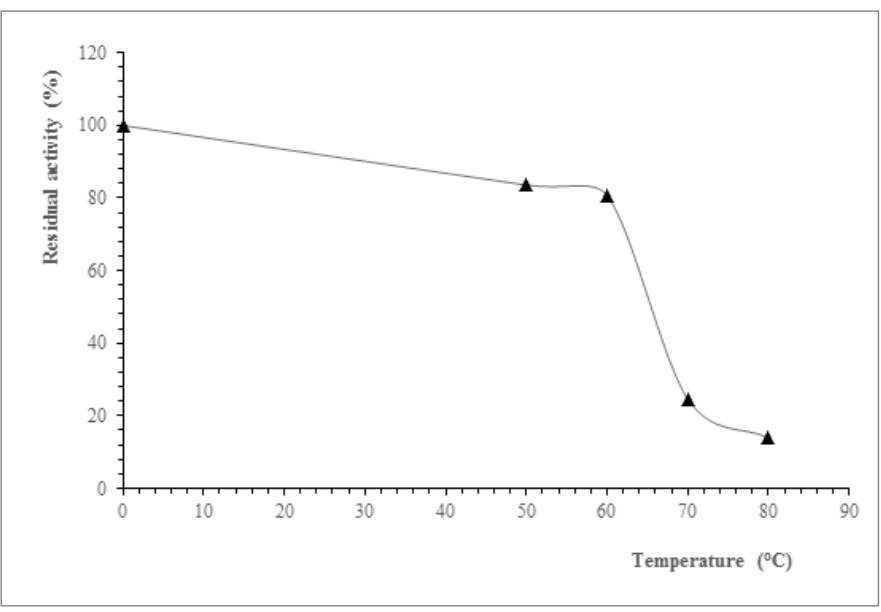

Figure 6: Thermal stability of CPrP. CPrP was incubated at $50^{\circ} \mathrm{C}, 60^{\circ} \mathrm{C}, 70^{\circ} \mathrm{C}$, and $80^{\circ} \mathrm{C}$ for 1 hour and then cooled on ice for 5 minutes prior to assay for peroxidase activity. Residual peroxidase activities were assayed as usual using o-dianinsidine $(5 \mathrm{mM})$ as substrate. Each reaction was initiated by the addition of $3 \%$ of $\mathrm{H}_{2} \mathrm{O}_{2}$ to the reaction mixture containing $2.7 \mathrm{ml}$ of $0.1 \mathrm{M}$ phosphate buffer solution (pH 6.0), plus $100 \mu 1$ of crude enzyme, and $100 \mu 1$ of substrate and change in A460 was monitored immediately after starting the reaction at 20-second intervals for 3 minutes.

$14 \%$ of the original activity was retained at the highest tested temperature $\left(80^{\circ} \mathrm{C}\right)$.

\subsubsection{Kinetics and substrate specificity of $\mathrm{CPrP}$}

Table 2 shows the $K_{\mathrm{m}}$ and $V_{\max }$ values for CPrP, which were calculated from the straight-line equation of a plot of $1 / \mathrm{V}$ against $1 /[S]$ using guaiacol and $o$-dianisidine substrate (Figs. 7 and 8). The kinetic data revealed that the purified CPrP exhibited the highest turnover rate toward $o$-dianisidine with $V_{\max }$ of 78,740 $\mu$ mole/minute. as against $45,871 \mu \mathrm{mole} /$ minute. for guaiacol. The $o$-dianisidine had lower $K_{\mathrm{m}}(3.755 \mathrm{mM})$ which suggests a better binding affinity for $\mathrm{CPrP}$ than the guaiacol with a higher $K_{\mathrm{m}}$ value of $12.560 \mathrm{mM}$. 
Table 2: Kinetic parameters of CPrP.

\begin{tabular}{ccc} 
Substrate & \multicolumn{2}{c}{ Kinetic parameters } \\
& $\boldsymbol{K}_{\mathrm{m}}(\mathbf{m M})$ & $\boldsymbol{V}_{\max }(\mathbf{m M} /$ minute $)$ \\
\hline O-dianisidine & 3.755 & 78.740 \\
Guaiacol & 12.560 & 45.871 \\
\hline
\end{tabular}

The kinetic parameters $\left(K_{\mathrm{m}}\right.$ and $\left.V_{\max }\right)$ were calculated from the equation of straight line (Figs. 7 and 8):

$$
\begin{aligned}
& 1 / V=\left(K_{\mathrm{m}} / V_{\max }\right) \times(1 /[S])+\left(1 / V_{\max }\right) \text {---------------- (Lineweaver-Burk equation) } \\
& \uparrow \uparrow \uparrow \uparrow \uparrow
\end{aligned}
$$

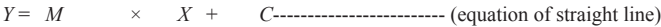

where $K_{\mathrm{m}}$ Michaelis-Menten constant for substrate $(\mathrm{mM}), V=$ Enzyme activity (Initial rate of reaction) $(\mu \mathrm{mole} / \mathrm{min} . \mathrm{ml}), V_{\max }=$ Maximum rate of reaction, and $[S]=$ concentration of substrate $(\mathrm{mM})$.

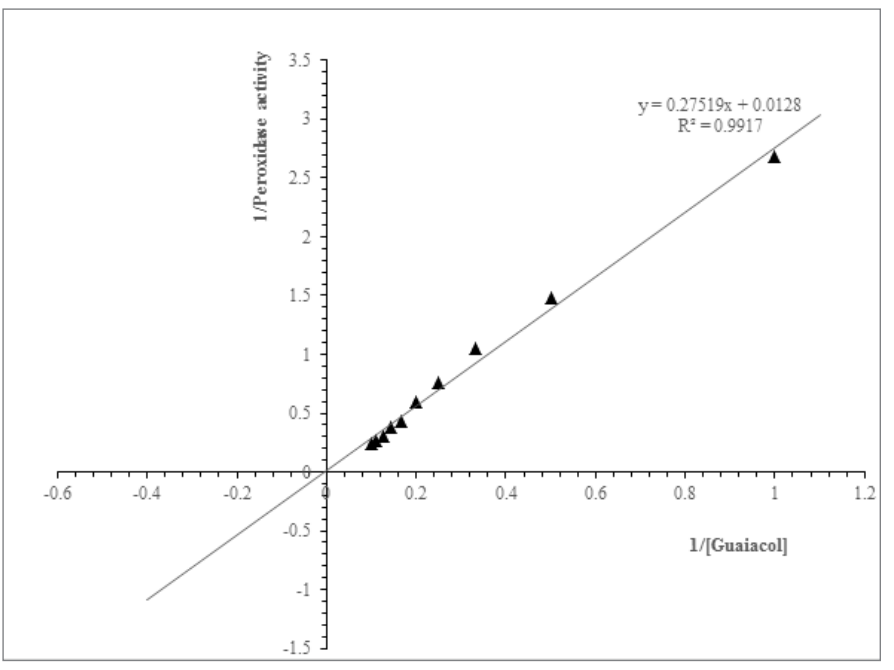

Figure 7: Lineweaver-Burk plot for $\mathrm{CPrP}$ using guaiacol as substrate. Peroxidase activity was assayed at varying concentrations of guaiacol $(0.1-1.0 \mathrm{mM})$. The reciprocal of the primary (peroxidase activity $v s$. substrate concentration) was fitted to the Lineweaver-Burk plot. Each reaction was initiated by the addition of $3 \%$ of $\mathrm{H}_{2} \mathrm{O}_{2}$ to the reaction mixture containing 2.7 $\mathrm{ml}$ of $0.1 \mathrm{M}$ Phosphate buffer solution (pH 6.0), plus $100 \mu \mathrm{l}$ of crude enzyme, and $100 \mu \mathrm{l}$ of substrate and change in A460 was monitored immediately after starting the reaction at 20 -second intervals for 3 minutes.

\subsubsection{Effects of metal ions, EDTA, organic solvent (acetone) on the activity of $\mathrm{CPrP}$}

The analyses of the effect of the divalent cations, acetone, and EDTA on CPrP activity revealed that $\mathrm{Hg}^{2+}$ (the only metal ion), acetone, and EDTA inhibited the purified enzyme (Table 3). However, all other tested metal ions exerted a slight activation effect on CPrP activity (Table 3 ).

\subsection{Potential Application of CPrP in Biodegradation of Phenol from Petroleum waste Effluent}

The mean phenol concentration in the petroleum effluent sample before CPrP-mediated treatment was estimated to be $19.4 \mathrm{mg} / \mathrm{l}$. An increase in efficiency of petroleum effluent phenol biodegradation with an increase in concentrations of purified enzyme suggests that $\mathrm{CPrP}$ is responsible for biodegradation (Table 4). The CPrP exhibited high efficiency for phenol removal from the effluent with up to $85 \%$ phenol biodegradation at the highest tested enzyme concentration after 60 minutes. Figure 9 shows the phenol

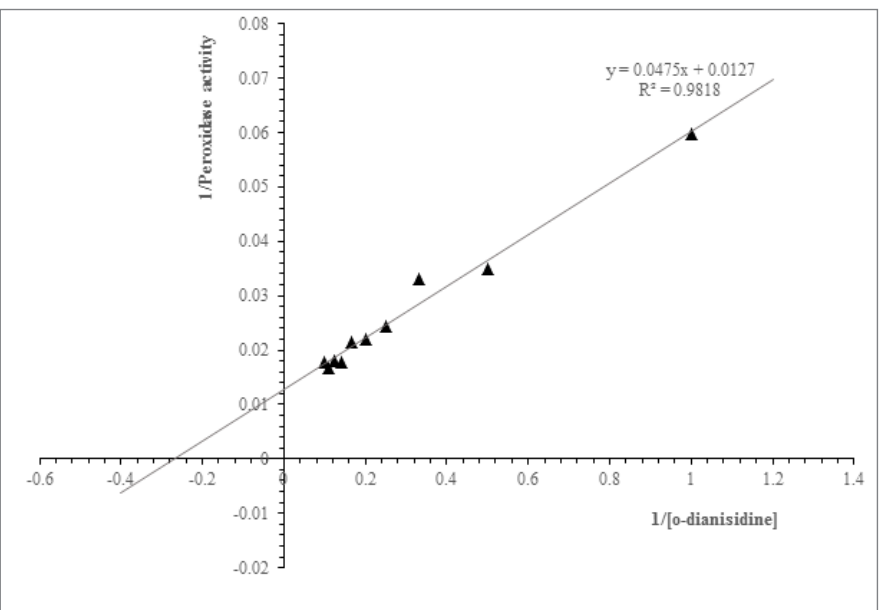

Figure 8: Lineweaver-Burk plot CPrP using o-dianisidine as substrate. Peroxidase activity was assayed at varying concentrations of o-dianisidine $(0.1-1.0 \mathrm{mM})$. The reciprocal of the primary (peroxidase activity $v s$. substrate concentration) were fitted to the Lineweaver-Burk plot. Each reaction was initiated by the addition of $3 \%$ of $\mathrm{H}_{2} \mathrm{O}_{2}$ to the reaction mixture containing 2.7 $\mathrm{ml}$ of $0.1 \mathrm{M}$ phosphate buffer solution ( $\mathrm{pH}$ 6.0), plus $100 \mu \mathrm{l}$ of crude enzyme, and $100 \mu \mathrm{l}$ of substrate and change in A460 was monitored immediately after starting the reaction at 20 -second intervals for 3 minutes.

Table 3: Effects of metal ions, organic solvent (acetone), and chemicals (EDTA and urea) on CPrP.

\begin{tabular}{ccc}
$\begin{array}{c}\text { Meta ions, acetone and } \\
\text { EDTA (5 mM) }\end{array}$ & $\begin{array}{c}\text { Peroxidase activity } \\
\text { (mmole/minute) }\end{array}$ & Residual activity (\%) \\
\hline $\begin{array}{c}\text { Control (No reagent) } \\
\mathrm{HgSO}_{4}\end{array}$ & 8.7 & 100 \\
$\mathrm{MgSO}_{4}$ & 4.626316 & 53.17604 \\
$\mathrm{ZnSO}_{4}$ & 8.921053 & 102.5408 \\
$\mathrm{CuSO}_{4}$ & 8.842105 & 101.6334 \\
$\mathrm{MnCl}_{2}$ & 8.842105 & 101.6334 \\
EDTA & 9.473684 & 108.8929 \\
Acetone & 6.457895 & 74.22868 \\
\hline
\end{tabular}

The effect of metal ions/chemicals on peroxidase activity was determined by pre-incubating the CPrP with individual divalent metal ion $\left(\mathrm{Mg}^{2+}, \mathrm{Hg}^{2+}, \mathrm{Zn}^{2+}, \mathrm{Cu}^{2+}\right.$, and $\left.\mathrm{Mn}^{2+}\right)$, EDTA and acetone a final concentration of $5 \mathrm{mM}$ for 30 minutes at $60^{\circ} \mathrm{C}$ prior to starting the reaction. The peroxidase activity in the absence of metal ion and EDTA and acetone was taken as the control.

Residual peroxidase activities $(\%)$ were calculated as $=($ peroxidase activity the presence of metal ion and EDTA and acetone/the peroxidase activity in the absence of metal ion and EDTA and acetone)*100

calibration curve used to extrapolating the phenol concentration before and after the enzymatic treatment of the effluent sample.

\section{DISCUSSION}

Peroxidase was partially purified and characterized from C. procera root and its practical application in biodegradation of petroleum waste effluent was tested. The purification fold and yield are quite high when compared to the one reported for peroxidase from $C$. procera leaves [19], Brassica oleracea L. var. italica stems [16], and Phoenix dactylifera L. leaves [25]. However, the purity of CPrP was lower than that of Moringa oleifera leaves peroxidase; this could be due to more purification steps used as reported by Khatun et al. [26]. The molecular weight of the majority of monomeric plant peroxidases varies from 30 to $60 \mathrm{kDa}[26,27]$. Findings from this study indicate that the $\mathrm{CPrP}$ is a monomer with a molecular weight of $46.5 \mathrm{kDa}$ as against reported (values for pother plant peroxidases) 
Joel et al.: Characterization of Calotropis procera root peroxidase and its potential to mediate remediation of phenolic pollutant from petroleum refinery effluent 2021;9(05):101-109

Table 4: Effect of CPrP on phenol removal from petroleum waste effluent

\begin{tabular}{ccccc}
$\begin{array}{c}\text { Initial phenol conc. from } \\
\text { industrial effluent }(\mathbf{m g} / \mathbf{L})\end{array}$ & $\begin{array}{c}\text { Industrial effluent }+ \\
\text { partially purified } \mathbf{C P r P}(\mathbf{m l})\end{array}$ & $\begin{array}{c}\text { Final phenol conc. } \\
(\mathbf{m g} / \mathbf{l})\end{array}$ & $\begin{array}{c}\text { \% Residual phenol } \\
\text { conc. }\end{array}$ & $\begin{array}{c}\text { \% Phenol biodegradation or } \\
\text { removal }\end{array}$ \\
\hline 19.4 & 0 & 19.38051 & 100 & 0.10043966 \\
19.4 & 0.1 & 13.55331 & 69.93266 & 30.1375834 \\
19.4 & 0.2 & 7.762868 & 40.05501 & 59.9852183 \\
19.4 & 0.4 & 2.854779 & 14.73015 & 85.2846422 \\
\hline
\end{tabular}

The efficiency of phenol removal was calculated by comparing phenol concentration in post-reaction mixture to the phenol concentration in the untreated petroleum effluent. The efficiency of phenol removal (\% removal) was thus calculated as follows:

$\%$ Phenol removal $=\left(C_{\text {initial }}-C_{\text {final }}\right) / C_{\text {initial }} * 100$.

where $C_{\text {initial }}$ is the initial concentration $(\mathrm{mg} / \mathrm{l})$ and $C_{\text {final }}$ is the final phenol concentration $(\mathrm{mg} / \mathrm{l})$

The absorbances obtained were used to calculate the corresponding phenol concentrations from the equation of straight line (Fig. 9).

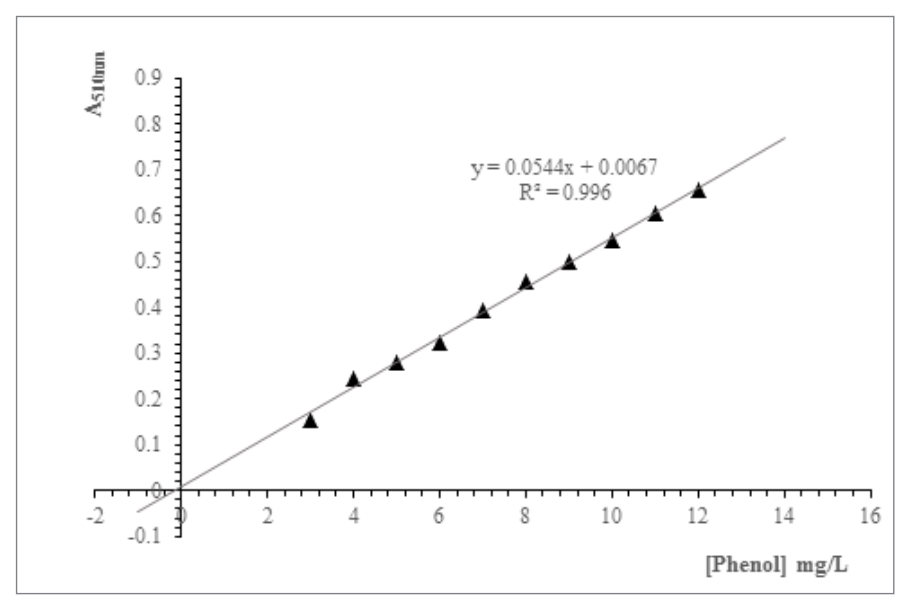

Figure 9: Phenol calibration curve. In order to quantify the phenol in industrial effluent before and after CPrP treatment a standard curve was made using 3-12 $\mathrm{mg} / \mathrm{l}$ pure phenol. To determine the residual phenol concentration, $4 \mathrm{ml}$ of $0.25 \mathrm{M}$ sodium bicarbonate and $0.9 \mathrm{ml}$ of $20.8 \mathrm{mM} 4$-aminoantipyrene were added to the samples. After vigorous mixing, $0.9 \mathrm{ml}$ of $83.4 \mathrm{mM}$ potassium ferricyanide was added, mixed, and allowed to stand for 9 minutes. Absorbance was measured at $510 \mathrm{~nm}$ using ultraviolet-visible (UV-vis) spectrophotometer and converted to concentration using calibration curve.

$42 \mathrm{kDa}$ for Caralluma umbellata [28], $43 \mathrm{kDa}$ for M. oleifera leaves [26], and $46.5 \mathrm{kDa}$ for vanilla bean [29].

The optimum temperature and $\mathrm{pH}$ of an enzyme are influenced by the source of an enzyme. The optimum temperature and $\mathrm{pH}$ are common intrinsic enzyme properties for the biochemical characterization of enzymes. The optimum $\mathrm{pH} \mathrm{CPrP}$ was similar to that obtained for peroxidase from $C$. procera leaves in our previous work [19]. According to previous research, the majority of the characterized plant peroxidases from various sources have optimum activity in the $\mathrm{pH}$ range of $4.5-6.5$ [30,31]. The optimum temperature of $\mathrm{CPrP}$ reported in this work is similar to that of $C$. procera leaves peroxidase in our previous work and that for $M$. oleifera leaves peroxidase $[19,26]$. The thermal stability profile suggests that CPrP is a thermostable enzyme. The instability of CPrP at extremely high temperatures could likely be due to the unfolding of the protein tertiary structure [25].

$\mathrm{Mn}^{2+}, \mathrm{Cu}^{2+}, \mathrm{Mg}^{2+}$, and $\mathrm{Zn}^{2+}$ slight activation of purified $\mathrm{CPrP}$ activity in a similar trend with the peroxidase of $P$. dactylifera $\mathrm{L}$. [32]. The inhibitory effects of $\mathrm{Hg}^{2+}$ and EDTA follow a similar trend to our previous report for peroxidase from $C$. procera leaves [19] and M. oleifera leaves peroxidase [26]. It has been documented that $\mathrm{Hg}^{2+}$ exerts its inhibitory effect on protein enzymes via binding to sulfhydryl groups at the active site of the enzyme, thus irreversibly inactivating the enzymes [33]. A well-known chelating agent, EDTA, usually exerts its inhibitory effect by chelating $\mathrm{Fe}^{2+}$ of heme-active center that is essential for catalysis of peroxidases [34].

Peroxidases usually catalyze the oxidation of a broad range of substrates in the presence of hydrogen peroxide [35]. The purified CPrP was active on both the two tested substrates exhibited with distinctive preference under similar assay conditions. The $o$-dianisidine reported in this study as the most preferred substrate is similar to date palm leaves ( $P$. dactylifera L.) peroxidase [25]. The distinctive substrate specificity could be due to the difference in the chemical nature of the substrates [36]. The kinetic data revealed a high $V_{\max }$ and low $K_{\mathrm{m}}$, which signifies a high catalytic activity and affinity of $\mathrm{CPrP}$ for $o$-dianisidine than guaiacol. The kinetic data follow a similar trend with that of date palm leaves (P. dactylifera L.) peroxidase [25].

The ability of peroxidases to catalyze the oxidation of various aromatic pollutants has been utilized for practical application in the bioremediation of organic contaminants like phenol and their derivatives from industrial effluents. Peroxidases are associated with the bioremediation of phenol from industrial effluent [37]. We recently characterized waste cabbage (B. oleracea capitata L.) peroxidase and also demonstrate its potential to degrade azo dyes and phenol from wastewater [14]. Findings from this study suggest that CPrP exhibits a high potential for bioremediation of phenol from petroleum refinery effluent. The capability of CPrP to degrade phenol from effluent was carried out under optimum reaction conditions established from the characterization of biochemical properties. The increase in percentage phenol removal with an increase in the concentration of the purified enzyme is an indication that CPrP was responsible for the biodegradation of phenol from petroleum effluent. The percentage removal of phenol by $\mathrm{CPrP}$ was quite better than our recent report for waste cabbage peroxidase [14]. However, the percentage of degradation of phenol by CPrP was lower than the values reported for horseradish (Armoracia rusticana) peroxidase [38] and immobilized turnip peroxidase [39]. Therefore, this variation in percentage biodegradation of phenol reported by various researchers could be due to variation in level purification, the concentration of enzymes, reaction time, native/immobilized enzyme, and addition of polyethylene glycol to the reaction medium. Having established the potential of peroxidase to degrade toxic pollutant phenol, findings from this work offer recommendations for further studies on the stability and 
immobilization to protect and improve the catalytic efficiency of the enzyme to know its suitability for practical industrial application.

Calotropis procera is a drought-resistant local plant that grows wild in the natural habitat of Nigerian throughout the year. Therefore, $C$. procera root could be an environmentally sustainable source of peroxidase for a low technological solution for phenol remediation.

\section{CONCLUSION}

In our quest to mitigate environmental pollution, this research project initiative targets mining of low-cost enzymes with potential for practical industrial application as a strategy to remediate the oil spillage polluted sites in the Niger Delta region of Nigeria. Some of the important properties of an enzyme required for industrial biocatalysis are that they are the local and readily abundant source, wide substrate specificity, and thermal stability. C. procera that is a drought-resistant local plant that grows wild in the natural habitat of Nigerian throughout the year could be a good and cheap source of peroxidase with a promising potential to remediate phenolic polluted water and soil.

This study demonstrated that CPrP with high catalytic activity and thermal stability which is obtained from a readily abundant root of $C$. procera exhibits potential for remediation of phenol from petroleum refinery effluent in the laboratory. Hence, CPrP could be a prospective and viable tool for oxidizing various organic phenolic contaminants of industrial wastes.

\section{CONFLICT OF INTEREST}

All authors have declared no conflicts of interest.

\section{FUNDING}

This research was not funded by any organization.

\section{ETHICAL APPROVALS}

This study does not involve experiments on animals or human subjects.

\section{PUBLISHER'S NOTE}

This journal remains neutral with regard to jurisdictional claims in published institutional affiliation.

\section{REFERENCES}

1. Viswanath B, Rajesh B, Janardhan A, Kumar AP, Narasimha G. Fungal laccases and their applications in bioremediation. Enzyme Res 2014;2014:1-21.

2. Osin OA, Yu T, Lin S. Oil refinery wastewater treatment in the Niger Delta, Nigeria: current practices, challenges, and recommendations. Environ Sci Pollut Res 2017;24(28):22730-40.

3. Viggor S, Jõesaar M, Soares-Castro P, Ilmjärv T, Santos PM, Kapley A, et al. Microbial metabolic potential of phenol degradation in wastewater treatment plant of crude oil refinery: analysis of metagenomes and characterization of isolates. Microorganisms 2020;8(5):1-26.

4. Bazrafshan E, Mostafapour FK, Faridi H, Zazouli MA. Application of moringa peregrina seed extract as a natural coagulant for phenol removal from aqueous solutions. Afr J Biotechnol 2012;11(103):16758-66.
5. Kolhe $\mathrm{P}$, Ingle $\mathrm{S}$, Wagh $\mathrm{N}$. Degradation of phenol containing wastewater by advance catalysis system - a review. Annu Res Rev Biol 2015;8(3):1-15.

6. El-Naas MH, Al-Zuhair S, Alhaija MA. Removal of phenol from petroleum refinery wastewater through adsorption on date-pit activated carbon. Chem Eng J 2010;162(3):997-1005. Available via http://dx.doi.org/10.1016/j.cej.2010.07.007

7. EPA. Technical support document for water quality-based toxic control. United States Environ Prot Agency 1991;2:1-335.

8. Baker EL, Landrigan PJ, Bertozzi PE. Phenol poisoning due to contaminated drinking water. Arch Environ Health 1978;33(2):89-94.

9. Miland E, Smyth MR, Fágáin CÓ. Phenol removal by modified peroxidases. J Chem Technol Biotechnol 1996;67(3):227-36. Available via http:/doi.wiley.com/10.1002/\%28SICI\%291097-4660 $\% 28199611 \% 2967 \% 3$ A 3\%3C227\%3A\%3AAID-JCTB563\%3 E3.0.CO\%3B2-J (Accessed 18 December 2019)

10. Chiong T, Lau S, Khor E, Danquah M. Enzymatic approach to phenol removal from wastewater using peroxidases. OA Biotechnol 2014;10(3):1-6.

11. Veitch NC. Horseradish peroxidase: a modern view of a classic enzyme. Phytochemistry 2004;65(3):249-59. Available via http:// www.ncbi.nlm.nih.gov/pubmed/14751298

12. Brill A. Peroxidase and catalase. In: Florkin, Stotz (eds.). Comprehensive biochemistry. 3rd edition. Elsevier, Amsterdam, The Netherlands, vol. 14, pp 447-79, 1971.

13. Chiong T, Lau SY, Khor EH, Danquah MK. Peroxidase extraction from jicama skin peels for phenol removal. IOP Conf Ser Earth Environ Sci 2016;36(1):012048.

14. Joel EB, Mafulul SG, Adamu HE, Goje LJ, Tijjani H, Igunnu A, et al. Peroxidase from waste cabbage (Brassica oleracea capitata L.) exhibits the potential to biodegrade phenol and synthetic dyes from wastewater. Sci Afr 2020;10:1-16.

15. Idesa GD, Getachew B. Extraction and partial purification of peroxidase enzyme from plant sources for antibody labeling. Int J Vet Sci Technol 2018;3(1):10-6. Available via www.scireslit.com

16. Ahmad Q, Mehmood A, Saeed Z, Fayyaz M. Purification and characterization of peroxidase from broccoli (Brassica oleracea 1. Var. Italica). Stems. Electron J Biol 2019;15(1):38-45.

17. Rusdi B, Mulyanti D, Rodiyah M. Characterization of peroxidase enzyme from water Spinach (Ipomoea aquatica Forssk.) fraction. Procedia Chem 2014;13:170-6. Available via http://dx.doi. org/10.1016/j.proche.2014.12.022

18. Adnan Abbas A. Extraction, purification and characterization of peroxidase from cabbage. Iraqi J Sci 2015;56(3):2282-91.

19. Mafulul S, Joel E, Barde L, Lenka J, Ameh A, Phililus M. Extraction, partial purification and characterization of peroxidase from Calotropis procera leaves. J Adv Biol Biotechnol 2018;18(1):1-10.

20. Geng Z, Rao KJ, Bassi AS, Gijzen M, Krishnamoorthy N. Investigation of biocatalytic properties of soybean seed hull peroxidase. Catal Today 2001;64(3-4):233-8.

21. Schagger H, Cramer WA, Vonjagow G. Analysis of molecular masses and oligomeric states of protein complexes by blue native electrophoresis and isolation of membrane protein complexes by twodimensional native electrophoresis. Anal Biochem 1994;217(2):220 30. Available via http://linkinghub.elsevier.com/retrieve/pii/ S0003269784711122

22. Łobarzewski J, Brzyska M, Wójcik A, Kolarz B. The influence of metal ions on the soluble and immobilized cytoplasmic cabbage peroxidase activity and its kinetics. J Mol Catal 1990;59(3):37383. Available via https://www.sciencedirect.com/science/article/ pii/030451029085109U (Accessed 19 May 2019)

23. Laemmli UK. Cleavage of structural proteins during the assembly of the head of the Bacteriophage T4. Nature 1970;227(5259):680-5.

24. Kinsley C, Nicell JA. Treatment of aqueous phenol with soybean peroxidase in the presence of polyethylene glycol. Bioresour Technol. 2000;73(2):139-46. 
25. Al-Senaidy AM, Ismael MA. Purification and characterization of membrane-bound peroxidase from date palm leaves (Phoenix dactylifera L.). Saudi J Biol Sci 2011;18(3):293-8.

26. Khatun S, Ashraduzzaman, Karim R, Pervin F, Absar N, Rosma A. Purification and characterization of peroxidase from Moringa oleifera 1. leaves. Bioresour 2012;7(3):3237-51.

27. Kokkinakis DM, Brooks JL. Tomato peroxidase. Plant Physiol 1979;63(1):93-9.

28. Achar RR, Venkatesh BK, Vivek HK, Priya BS, Swamy SN. Caralluma umbellata peroxidase: biochemical characterization and its detoxification potentials in comparison with horseradish peroxidase. Appl Biochem Biotechnol 2017;181(2):801-12. Available from: http://dx.doi.org/10.1007/s12010-016-2250-1

29. Márquez O, Waliszewski KN, Oliart RM, Pardio VT. Purification and characterization of cell wall-bound peroxidase from vanilla bean. LWT - Food Sci Technol 2008;41(8):1372-9.

30. Leon JC, Alpeeva I, Chubar T, Galaev IY, Csoregi E, Sakharov IY. Purification and substrate specificity of peroxidase from sweet potato tubers. Plant Sci 2002;163(5):1011-1019. Available via https://www. sciencedirect.com/science/article/pii/S0168945202002753 (Accessed 25 April 2019)

31. Deepa SS, Arumughan C. Purification and characterization of soluble peroxidase from oil palm (Elaeis guineensis Jacq.) leaf. Phytochemistry 2002;61(5):503-11. Available via https://www.sciencedirect.com/ science/article/abs/pii/S003194220200167X?via\%3Dihub (Accessed 26 April 2019)

32. Al-Senaidy AM, Ismael MA. Purification and characterization of membrane-bound peroxidase from date palm leaves (Phoenix dactylifera L.). Saudi J Biol Sci 2011;18(3):293-8.

33. Vallee BL, Ulmer DD. Biochemical effects of mercury, cadmium, and lead. Annu Rev Biochem 1972;41(1):91-128. Available from: http:// www.annualreviews.org/doi/10.1146/annurev.bi.41.070172.000515 (Accessed 19 May 2019)

34. Dębowska R, Podstolski A. Properties of diphenolase from Vanilla planifolia (Andr.) shoot primordia cultured in vitro. J Agric Food Chem 2001;49(7):3432-7. Available via https://pubs.acs.org/doi/10.1021/ jf001180z
35. Malomo SO, Adeoye RI, Babatunde L, Saheed IA, Iniaghe MO, Olorunniji FJ. Biokemistri suicide inactivation of horseradish peroxidase by excess hydrogen peroxide: the effects of reaction $\mathrm{pH}$, buffer ion concentration, and redox mediation. Biokemistri 2011;23:124-8.

36. Diao M, N'cho Ayékoué B, Dibala CI, Dabonné S, Dicko MH. Purification and characterization of sweet potato (Ipomoea batatas) peroxidase. J Anim Plant Sci 22(2):3419-32. Available via http:// www.m.elewa.org/JAPS;ISSN2071-7024 (Accessed 25 April 2019).

37. Singh NSJ. An enzymatic method for removal of phenol from an enzymatic method for removal of phenol from. Prep Biochem Biotechnol 2002;32(2):127-133; doi:10.1081/PB-120004125

38. Stanisavljević M, Nedić L. Removal of phenol from industrial wastewaters by horseradish-Cochlearia armoracia L-peroxidase. Facta Univ Work 2004;2:345-9. Available via http://scindeks.ceon.rs/ article.aspx?artid=0354-804X0404345S

39. Quintanilla-Guerrero F, Duarte-Vázquez MA, García-Almendarez BE, Tinoco R, Vazquez-Duhalt R, Regalado C. Polyethylene glycol improves phenol removal by immobilized turnip peroxidase. Bioresour Technol 2008;99(18):8605-11.

\section{How to cite this article:}

Joel EB, Mafulul SG, Jeremiah EA, Aberuagba A, Adeoye RI, Goje LJ, Igunnu A, Malomo SO. Characterization of Calotropis procera root peroxidase and its potential to mediate remediation of phenolic pollutant from petroleum refinery effluent. J Appl Biol Biotech 2021; 9(05):101-109. 